Medical Principles and Practice
Med Princ Pract 2012;21:249-253

DOI: $\underline{10.1159 / 000334588}$
Received: April 10, 2011

Accepted: October 18, 2011

Published online: December 16, 2011

\title{
Inflammatory Biomarkers in Patients with Asymptomatic Primary Hyperparathyroidism
}

\author{
Ahmed Alsayed Emam ${ }^{a} \quad$ Sabela Gomaa Mousa ${ }^{b}$ Karema Yousif Ahmed ${ }^{b}$ \\ Adel A. Al-Azab ${ }^{C}$ \\ ${ }^{a}$ Department of Internal Medicine, National Research Center, ${ }^{b}$ Department of Internal Medicine, \\ Al-Azhar University, and ${ }^{\mathrm{C} C l i n i c a l}$ Pathology, Ain Shams University, Cairo, Egypt
}

\section{Key Words}

Asymptomatic primary hyperparathyroidism $\cdot$ Highly

sensitive C-reactive protein • Interleukin-6

\section{Abstract}

Objective: To assess highly sensitive C-reactive protein (hsCRP) and interleukin-6 (IL-6) as inflammatory biomarkers in patients with asymptomatic primary hyperparathyroidism (PHPT). Materials and Methods: A total of 26 patients with asymptomatic PHPT and 22 age- and sex-matched individuals as a control group were recruited for the study. Corrected serum calcium, phosphorus, alkaline phosphatase, serum 25-hydroxyvitamin $\mathrm{D}$, intact parathyroid hormone (PTH), hs-CRP and IL- 6 were measured for all subjects. Results: Serum hs-CRP and IL- 6 were significantly higher in asymptomatic PHPT patients than in the control group (hs-CRP: $4.15 \pm$ 0.54 vs. $2.24 \pm 0.11 \mathrm{mg} / \mathrm{l} ; \mathrm{IL}-6: 4.50 \pm 0.80$ vs. $2.56 \pm 0.29 \mathrm{pg} /$ $\mathrm{ml} ; \mathrm{p}<0.001)$. Moreover, in asymptomatic PHPT patients, serum PTH was significantly correlated with hs-CRP and IL-6 $(r=0.820, p<0.001$ and $r=0.787, p<0.001$, respectively). Conclusion: Inflammatory biomarkers were higher in patients with asymptomatic PHPT than in controls. Moreover, serum PTH was significantly correlated with inflammatory biomarkers which may suggest a subclinical inflammatory response in this group of patients.

Copyright $\odot 2011$ S. Karger AG, Basel

\section{Introduction}

Primary hyperparathyroidism (PHPT) is a hypercalcemic state due to excessive secretion of parathyroid hormone (PTH) [1]. The disease is characterized by a loss of the normal feedback control of PTH by extracellular calcium, but the exact underlying cause remains to be clarified [2]. Comparable to limited studies in developing countries, the clinical spectrum of PHPT has undergone a striking change in developed countries, with the predominant form being asymptomatic hyperparathyroidism, detected on routine biochemical screening for other causes [3]. Asymptomatic PHPT is defined as hyperparathyroidism that lacks specific symptoms or signs traditionally associated with hypercalcemia or PTH excess [4].

Inflammation and endothelial cell activation are key components in the initiation, progression and thrombot-

\section{KARGER}

Fax +4161306 1234

E-Mail karger@karger.ch

www.karger.com
(C) 2011 S. Karger AG, Basel

$1011-7571 / 12 / 0213-0249 \$ 38.00 / 0$

Accessible online at:

www.karger.com/mpp
Dr. Ahmed Alsayed Emam

Department of Internal Medicine

National Research Center

Dokki, Giza (Egypt)

Tel. +20 118810 000, E-Mail ahmedemam6@ hotmail.com 
ic complications of atherosclerotic coronary artery disease. Serum highly sensitive C-reactive protein (hs-CRP) and interleukin-6 (IL-6), both proinflammatory cytokines, as well as having pathogenic roles in atherosclerosis, have strong and independent prognostic implications in patients with atherosclerotic vascular disease and acute coronary syndromes [5].

IL-6 has an important role in immunoregulation and inflammation [6]. Also, elevated hs-CRP reflects lowgrade systemic inflammation. It is not only an established independent risk factor for cardiovascular events in adults, but is also apparently directly involved in atherogenesis [7].

Previous studies of PHPT have shown normal [8] or increased levels of basal IL- 6 compared to healthy controls [9, 10]. Grey et al. [11] demonstrated that patients with untreated PHPT had mean serum levels of IL-6 which were 16 -fold higher than the control values. After successful parathyroid adenomectomy, the levels of each of these cytokines fell into the normal range.

However, there are results with unchanged levels of inflammatory cytokines after the surgical cure of parathyroid disease. Ogard et al. [12] reported that CRP, but not IL-6, was higher in patients with PHPT than in controls, and no decrease in markers of inflammation or blood pressure was observed after parathyroidectomy. Data on inflammatory markers in asymptomatic PHPT are lacking and mainly derived from symptomatic patients. Hence, the aims of the present study were to assess hs-CRP and IL-6, such as inflammatory biomarkers, in patients with asymptomatic PHPT, and to evaluate the correlation between serum PTH and these biomarkers.

\section{Subjects and Methods}

A total of 26 patients with asymptomatic PHPT were recruited from outpatient endocrine and medical clinics at Al-Azhar University Hospital, Cairo, Egypt, together with 22 age- and sexmatched healthy subjects as control group.

The study was performed between the years 2008 and 2010. The patients gave informed voluntary consent to participate in the study according to the protocol approved by the local ethics committee and in accordance with the ethical standards of the Helsinki declaration. The diagnosis of PHPT was made by blood tests. All patients were subjected to a full case history and a thorough clinical examination. Inclusion criteria were PHPT with no symptoms or signs traditionally associated with hypercalcemia or PTH excess and not having fulfilled the criteria for parathyroidectomy. Exclusion criteria were obesity, diabetes mellitus, any previous history of ischemic stroke, hypertension, hyperlipidemia, history of ischemic heart disease, congestive heart failure, collagen diseases, advanced chronic liver or renal insufficiency, smoking, and drug use with impact on calcium-phosphate metabolism, such as calcium, vitamin D, thiazide diuretics, estrogen, bisphosphonates, calcitonin, thyroxin and corticosteroids.

\section{Laboratory Methods}

Fasting venous samples were collected. Blood sugar, calcium, albumin, phosphorus, alkaline phosphatase, liver and renal functions were measured using a standard autoanalyzer (Hitachi Ltd., Japan). Serum 25-hydroxyvitamin D [25(OH)D] was assessed by liquid phase radioimmunoassay after extraction with $\mathrm{NaOH}$ and acetonitrite, using an IDS gamma-beta 25(OH)D kit (IDS Inc., Fountain Hills, USA). Intact PTH was assayed by a solid phase 2 site chemiluminescent enzyme-labeled immunometric assay (DPC, Los Angeles, Calif., USA). Serum hs-CRP concentrations were measured using a high-sensitivity immunoradiometric assay [13]. IL-6 was measured with a high-sensitivity enzyme-linked immunoassay [14].

\section{Statistical Analysis}

The SPSS version 15 was used for data processing. Quantitative data were presented as mean and standard deviation. For comparison of means, the Student $t$ test was used. Correlation between variables was performed and the Pearson correlation coefficient was calculated. All tests were 2 -tailed and considered statistically significant at $\mathrm{p}<0.05$.

\section{Results}

The mean age of the patients (17 females and 9 males) with asymptomatic PHPT was $52.8 \pm 4.4$ years and that of the 22 healthy individuals ( 15 females and 7 males) in the control group was $51.7 \pm 5.9$ years.

Serum PTH levels in patients with asymptomatic PHPT and in the control group were $11.88 \pm 2.16$ and $3.85 \pm 0.90 \mathrm{pmol} / \mathrm{l}$, respectively, while the corresponding levels of serum calcium were $2.65 \pm 0.1$ and $2.22 \pm 0.04$ $\mathrm{mmol} / \mathrm{l}$. The differences were statistically significant $(\mathrm{p}<$ 0.001). Also, serum hs-CRP and IL- 6 were significantly higher in patients with asymptomatic PHPT in comparison with the control group (hs-CRP: $4.15 \pm 0.54$ vs. 2.24 $\pm 0.11 \mathrm{mg} / \mathrm{l}$; IL-6: $4.50 \pm 0.80$ vs. $2.56 \pm 0.29 \mathrm{pg} / \mathrm{ml}$; $\mathrm{p}<0.001)$. However, serum phosphorus, alkaline phosphatase and 25(OH)D showed nonsignificant differences between the two groups $\left[\mathrm{PO}_{4}: 1.37 \pm 0.09\right.$ vs. $1.31 \pm 0.07$ $\mathrm{mmol} / \mathrm{l}$, alkaline phosphatase: $88.1 \pm 4.33$ vs. $85.7 \pm$ $6.36 \mathrm{IU} / \mathrm{l} ; 25(\mathrm{OH}) \mathrm{D}: 93.6 \pm 6.4$ vs. $89.6 \pm 6.6 \mathrm{nmol} / \mathrm{l}$; $\mathrm{p}<0.05$ ] as shown in table 1 .

\section{Correlation with Inflammatory Biomarkers}

Serum PTH was significantly correlated with hs-CRP and IL- $6(\mathrm{r}=0.820, \mathrm{p}<0.001$ and $\mathrm{r}=0.787, \mathrm{p}<0.001$, respectively) in patients with asymptomatic PHPT as shown in figure 1. 


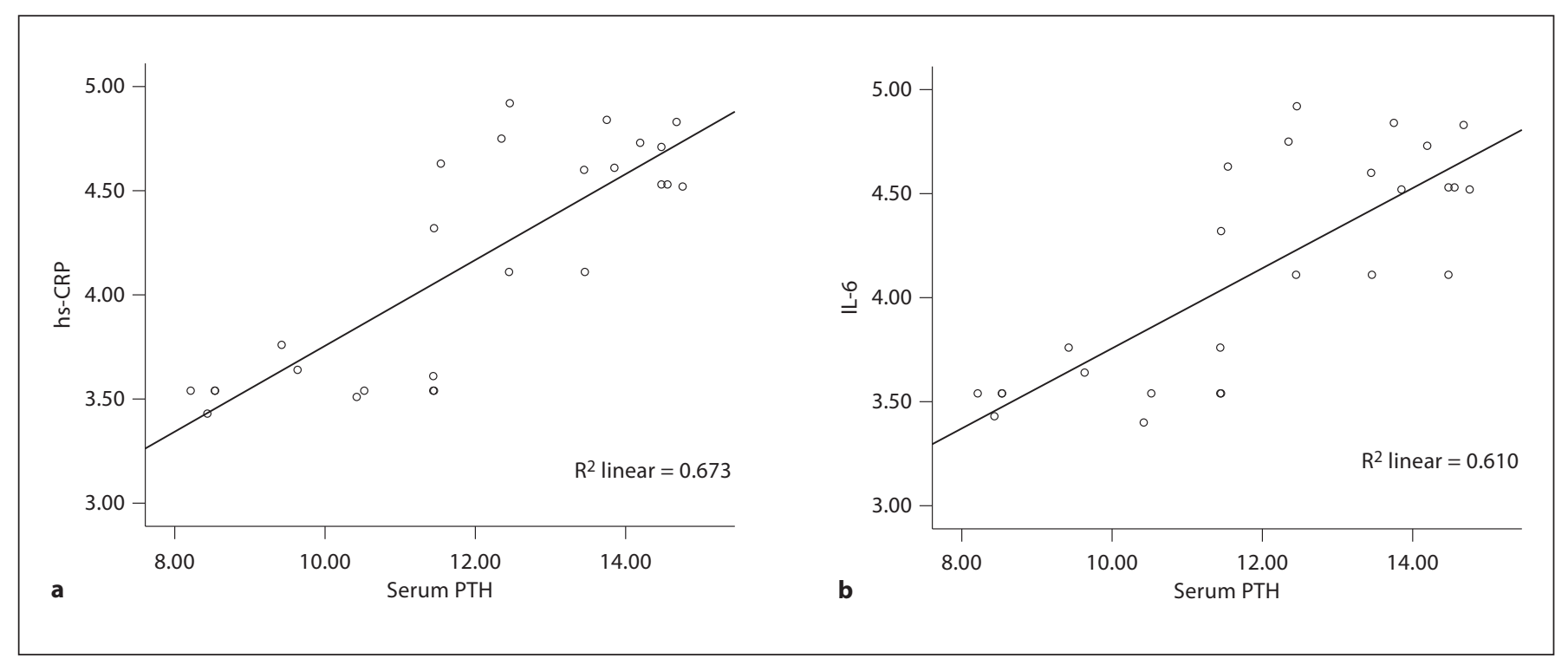

Fig. 1. Correlation between PTH and hs-CRP (a) and IL-6 (b) in asymptomatic PHPT patients.

\section{Discussion}

PHPT is a common disease, especially in the elderly, and is reported to be associated with increased morbidity and mortality from cardiovascular disease [15]. Currently, PHPT has been recognized most commonly as an asymptomatic disorder with hypercalcemia and elevated levels of PTH [16]. The role of PHPT in heart disease is still controversial [17].

IL-6 is a cytokine, which plays an important role in many chronic inflammatory diseases. Serum hs-CRP and IL- 6 are inflammatory markers associated with an increased risk of cardiovascular disease. Increased proinflammatory cytokines in serum initiate the atherosclerotic process and impair vascular endothelial function $[18,19]$. Also, IL-6 plays an important role in the acutephase response, acting to stimulate hepatic production of acute-phase proteins such as CRP $[20,21]$ in this study. The higher levels of hs-CRP and IL-6 in patients with asymptomatic PHPT compared to a control group could explain the previously described roles of these inflammatory markers in cardiovascular disease. Equally important, serum PTH was significantly correlated with hs-CRP and IL- 6 in the studied patients.

Although our patient did not fulfil the criteria for parathyroidectomy, similar results in terms of elevated IL- 6 which normalized after resection of parathyroid tumors have been obtained previously in patients with
Table 1. Baseline characteristics in asymptomatic PHPT patients and controls

\begin{tabular}{lll}
\hline & $\begin{array}{l}\text { PHPT patients } \\
(\mathrm{n}=26)\end{array}$ & $\begin{array}{l}\text { Controls } \\
(\mathrm{n}=22)\end{array}$ \\
\hline Age, years & $52.8 \pm 4.4$ & $51.7 \pm 5.9$ \\
Gender, f/m & $17 / 9$ & $15 / 7$ \\
Corrected serum calcium, mmol/l & $2.65 \pm 0.10^{*}$ & $2.22 \pm 0.04$ \\
$\mathrm{PO}_{4}, \mathrm{mmol} / \mathrm{l}$ & $1.37 \pm 0.09$ & $1.31 \pm 0.07$ \\
$\mathrm{ALP}, \mathrm{IU} / \mathrm{l}$ & $88.1 \pm 4.33$ & $85.7 \pm 6.36$ \\
25(OH)D, nmol/l & $93.6 \pm 6.4$ & $89.6 \pm 6.6$ \\
$\mathrm{PTH}, \mathrm{pmol} / \mathrm{l}$ & $11.88 \pm 2.16^{*}$ & $3.85 \pm 0.90$ \\
$\mathrm{hs}-\mathrm{CRP}, \mathrm{mg} / \mathrm{l}$ & $4.15 \pm 0.54^{*}$ & $2.24 \pm 0.11$ \\
$\mathrm{IL}-6, \mathrm{pg} / \mathrm{ml}$ & $4.50 \pm 0.80^{*}$ & $2.56 \pm 0.29$ \\
\hline
\end{tabular}

Data are expressed as means \pm SD or numbers. ALP $=$ Alkaline phosphatase. ${ }^{*} \mathrm{p}<0.001$ is highly significant.

PHPT $[22,23]$. Furthermore, circulating levels of both IL-6 and IL-6 soluble receptor are increased in humans in response to chronic PTH excess and short-term lowdose PTH infusion [24].

Contrary to our results, normal levels of basal IL- 6 and CRP in PHPT patients when compared to healthy controls have been reported $[8,25]$. Several factors could be adduced to explain the discrepancies between these studies and our observation. It might be related to the use of 
hs-CRP as a marker of inflammation instead of CRP, and importantly, one study [24] did not include healthy subjects as controls but depended on the normal reference range of the inflammatory markers.

The relationship between serum PTH and inflammation biomarkers such as IL-6 and CRP is not fully understood. It was reported that PTH potently induces hepatic production of bioactive IL- 6 and its soluble receptor by the rat liver ex vivo and that hepatocytes, liver endothelial cells and Kupffer cells each produce IL- 6 and IL-6 soluble receptor in response to PTH in vitro. Also, perfusion of the isolated rat liver with near-physiological concentrations of PTH stimulates production of both bioactive IL- 6 and IL- 6 soluble receptor, which suggests that hepatic production could contribute substantially to PTH-induced increases in systemic levels of IL- 6 and its soluble receptor [26].

Other studies have provided further evidence that the liver is a target organ for PTH $[27,28]$. The liver strongly expresses mRNA for the PTH/PTH-related protein receptor, which probably mediates the actions of PTH or PTH-related protein on the production of IL-6 and its soluble receptor and the acute-phase response [29] in liver tissue. It is unlikely that the PTH-2 receptor, which binds PTH more avidly than PTH-related protein, contributes to the effects of PTH on hepatic IL-6 production because, although it may be expressed in the liver, it is much less abundant there than the type $1 \mathrm{re}$ ceptor [30].

In the present study, the increased inflammatory biomarkers in asymptomatic PHPT may suggest a subclinical inflammatory state that helps the development of cardiovascular events in this category of patients.

\section{Conclusion}

The inflammatory biomarkers hs-CRP and IL-6 were significantly higher in patients with asymptomatic PHPT in comparison with the control group. Moreover, Serum PTH was significantly correlated with hs-CRP and IL-6 in asymptomatic PHPT, which may suggest a subclinical inflammatory response in this category of patients. Further studies are required to evaluate inflammatory biomarkers in asymptomatic PHPT patients (particularly with normal PTH values and slightly elevated calcium levels) with varying degrees of severity according to 1,25-vitamin D levels.

\section{Acknowledgments}

We would like to thank all the patients who participated in this study. We are grateful to all the staff in the medical clinic for their assistance in carrying out this study.

\section{References}

1 Birkenhäger JC, Bouillon R: Asymptomatic primary hyperparathyroidism. Postgrad Med J 1996;72:323-326.

$\checkmark 2$ Brown M: The pathophysiology of primary hyperparathyroidism. J Bone Miner Res 2002;17(suppl 2):N24-N29.

3 Wermers RA, Khosla S, Atkinson EJ, Hodgson SF, O'Fallon WM, Melton LJ 3rd: The rise and fall of primary hyperparathyrodism: a population-based study in Rochester, Minnesota, 1965-1992. Ann Intern Med 1997; 126:433-440.

4 Bilezikian JP, Khan AA, Potts JT Jr: Third International Workshop on the Management of Asymptomatic Primary Hyperthyroidism. Guidelines for the management of asymptomatic primary hyperparathyroidism: summary statement from the third international workshop. J Clin Endocrinol Metab 2009;94:335-339.

5 Koenig W, Khuseyinova N: Biomarkers of atherosclerotic plaque instability and rupture. Arterioscler Thromb Vasc Biol 2007;27: $15-26$.
-6 Buke AC, Buke M, Altuglu IE, Ciceklioglu M, Kamcioglu S, Karakartal G, Huseyinov A: Tumor necrosis factor alpha and interleukin 6 productions in response to platelet-activating factor in chronic hepatitis B virus infection. Med Princ Pract 2004;13:273-276.

7 Venugopal SK, Devaraj S, Yuhanna I, Shaul P, Jialal I: Demonstration that C-reactive protein decreases eNOS expression and bioactivity in human aortic endothelial cells. Circulation 2002;106:1439-1441.

8 Luboshitzky R, Chertok-Schaham Y, Lavi I, Ishay A: Cardiovascular risk factors in primary hyperparathyroidism. J Endocrinol Invest 2009;32:317-321.

-9 Nakchbandi IA, Mitnick MA, Lang R, Gundberg C, Kinder B, Insogna K: Circulating levels of interleukin- 6 soluble receptor predict rates of bone loss in patients with primary hyperparathyroidism. J Clin Endocrinol Metab 2002;87:4946-4951.
10 Safley SA, Villinger F, Jackson EH, TuckerBurden C, Cohen C, Weber CJ: Interleukin-6 production and secretion by human parathyroids. Clin Exp Immunol 2004;136:145156.

11 Grey A, Mitnick MA, Shapses S, Ellison A, Gundberg C, Insogna K: Circulating levels of interleukin- 6 and tumor necrosis factor-alpha are elevated in primary hyperparathyroidism and correlate with markers of bone resorption: a clinical research center study. J Clin Endocrinol Metab 1996;81:3450-3454.

12 Ogard CG, Engelmann MD, Kistorp C, Nielsen SL, Vestergaard H: Increased plasma $\mathrm{N}$-terminal pro-B-type natriuretic peptide and markers of inflammation related to atherosclerosis in patients with primary hyperparathyroidism. Clin Endocrinol (Oxf) 2005;63:493-498.

13 Hutchinson WL, Koenig W, Frohlich M, Sund M, Lowe GD, Pepys MB: Immunoradiometric assay of circulating C-reactive protein: age-related values in the adult general population. Clin Chem 2000;46:934938. 
14 Nagueh SF, Appleton CP, Gillebert TC, Marino PN, Oh JK, Smiseth OA, Waggoner AD, Flachskampf FA, Pellikka PA, Evangelisa A: Recommendations for the evaluation of left ventricular diastolic function by echocardiography. Eur J Echocardiogr 2009;10:165193.

15 Hedback G, Oden A: The increased risk of death of primary hyperparathyroidism: an update. Eur J Clin Invest 1998;28:271-276.

16 Silverberg SJ, Bilezikian JP: Clinical presentation of primary hyperparathyroidism in the United States; in Marcus R, Levine MA (eds): The Parathyroids. New York, Academic Press, 2001, pp 349-360.

- 17 Kiernan TJ, O’Flynn AM, McDermott JH, Kearney P: Primary hyperparathyroidism and the cardiovascular system. Int J Cardiol 2006;113:E89-E92.

18 Devaraj S, Singh U, Jialal I: The evolving role of C-reactive protein in atherothrombosis. Clin Chem 2009;55:229-238.

19 Abeywardena MY, Leifert WR, Warnes KE, Varghese JN, Head RJ: Cardiovascular biology of interleukin-6. Curr Pharm Des 2009; 15:1809-1821.
20 Gabay C, Kushner I: Acute-phase proteins and other systemic responses to inflammation. N Engl J Med 1999;340:448-454.

21 Heinrich PC, Castell JV, Andus T: Interleukin- 6 and the acute phase response. Biochem J 1990;265:621-636.

22 Safley SA, Villinger F, Jackson EH, TuckerBurden C, Cohen C, Weber CJ: Interleukin-6 production and secretion by human parathyroids. Clin Exp Immunol 2004;136:145156.

23 Nakchbandi IA, Mitnick MA, Masiukiewicz US, Sun BH, Insogna KL: IL-6 negatively regulates IL-11 production in vitro and in vivo. Endocrinology 2001;142:3850-3856.

24 Grey A, Mitnick M, Masiukiewicz U, Sun B-H, Rudikoff S, Jilka R, Manolagas S, Insogna K: A role for interleukin-6 in parathyroid hormone-induced bone resorption in vivo. Endocrinology 1999; 140:4683-4690.

25 Almqvist EG, Bondeson AG, Bondeson L, Svensson J: Increased markers of inflammation and endothelial dysfunction in patients with mild primary hyperparathyroidism. Scand J Clin Lab Invest 2011;71:139-144.
26 Mitnick MA, Grey A, Masiukiewicz U, Bartkiewicz M, Rios-Velez L, Friedman S, Xu L, Horowitz MC, Insogna K: Parathyroid hormone induces hepatic production of bioactive interleukin-6 and its soluble receptor. Am J Physiol Endocrinol Metab 2001; 280:E405-E412.

27 Tian J, Smogorzewski M, Kedes L, Massry SG: Parathyroid hormone-related protein receptor messenger RNA is present in many tissues besides the kidney. Am J Nephrol 1993;13:210-213

28 Urena P, Xiang-Fu K, Abou-Samra AB, Juppner H, Kronenberg HM, Potts JT, Segre GV: Parathyroid hormone (PTH)/PTH-related peptide receptor messenger ribonucleic acids are widely distributed in rat tissues. Endocrinology 1993;133:617-623.

29 Funk JL, Moser AH, Grunfeld C, Feingold KR: Parathyroid hormone-related protein is induced in the adult liver during endotoxemia and stimulates the hepatic acute phase response. Endocrinology 1997;138:26652673.

30 Usdin TB, Bonner TI, Harta G, Mezey E: Distribution of parathyroid hormone-2 receptor messenger ribonucleic acid in rat. Endocrinology 1996;137:4285-4297. 